\title{
Manusia yang Dijadikan Komoditas: Fenomena Human Trafficking di Provinsi Nusa Tengggara Timur
}

\author{
Edwardus Iwantri Goma \\ Program Studi Pendidikan Geografi, Fakultas Keguruan dan IImu Pendidikan, Universitas \\ Mulawarman, Samarinda
}

Korespondensi: Edwardus Iwantri Goma (e-mail: Edgoma27@gmail.com)

\begin{abstract}
Abstrak
Fenomena human trafficking yang menjadikan manusia sebagai komoditas perdagangan merupakan hal yang sangat memprihatinkan. Dalam beberapa tahun terakhir dari 2014 hingga 2018, angka kasus human trafficking di Provinsi Nusa Tenggara Timur (NTT) terus mengalami penigkatan. Pada 2017, Provinsi NTT menempati posisi tertinggi dari seluruh Provinsi di Indonesia terkait kasus human trafficking, dimana dari Januari hingga Agustus tercatat terdapat 137 kasus human trafficking di Provinsi NTT. Fakta ini tentu sangat memprihatinkan bagi segenap masyarakat dan pemerintah Provinsi NTT. Artikel ini bertujuan untuk mengetahui 1) realitas human trafficking di Provinsi NTT, 2) faktor penyebab terjadinya human trafficking di Provinsi NTT, dan 3) solusi untuk mengatasi human trafficking di Provinsi NTT. Artikel ini menggunakan metode studi pustaka dengan memanfaatkan data sekunder dari berbagai sumber yang relevan. Kasus human trafficking di Provinsi NTT mengalami peningkatan dari tahun ke tahun dan menunjukkan bahwa selama periode 2015 hingga pertengahan 2016, terdapat 1.667 tenaga kerja wanita (TKW) korban human trafficking di Provinsi NTT. Rendahnya sumber daya manusia (SDM) sebagai dampak dari tingkat pendidikan yang rendah dan masalah ekonomi, seperti kemiskinan dan tingginya tingkat pengangguran, merupakan penyebab utama terjadinya human trafficking di Provinsi NTT. Untuk mengatasi hal tersebut, perlu adanya solusi konkrit berupa tindakan preventif, pemberdayaan, dan perbaikan sistem ketenagakerjaan.
\end{abstract}

Kata kunci: komoditias; pekerja migran; sumber daya manusia; kemiskinan 


\title{
Human Being Made as a Commodity: The Phenomenon of Human Trafficking in East Nusa Tenggara Province
}

\begin{abstract}
The phenomenon of human trafficking that makes humans as a commodity of trade is something that very alarming. In recent years since 2014 to 2018 the number of human trafficking cases in East Nusa Tenggara province has increased more than in other regions in Indonesia. In 2017, East Nusa Tenggara Province was ranked first of all Provinces in Indonesia related to human trafficking cases, where from January to August there were 137 cases of human trafficking in East Nusa Tenggara Province. This fact is certainly very alarming for all the people and the East Nusa Tenggara government. This article aimed at finding out 1) reality of the human trafficking case in East Nusa Tenggara Province, 2) human trafficking factors in East Nusa Tenggara Province, and 3) a solution to overcome human trafficking in East Nusa Tenggara Province. This article used literature study method by utilizing secondary data from various relevant sources. Human trafficking in East Nusa Tenggara Province have increased from year to year, it was reported that during the period of 2015 to mid-2016 there were 1,667 female migrant workers of human trafficking victims in East Nusa Tenggara Province. Low human resources as a result of low level of education and economic problems such us poverty and high unemployment are that main causes of human trafficking in East Nusa Tenggara Province. To overcame this, it is necessary to have concrete solutions like preventive action, empowerment, and improvement of the labor system.
\end{abstract}

Keywords: commodity; migrant workers; human resources; poverty

\section{Pendahuluan}

Apa yang ada di benak Anda jika mendengar kata komoditas? Selama ini kata "komoditas" selalu identik dengan benda. Secara sederhana komoditas merupakan suatu benda yang dapat diperjualbelikan. Namun seiring berkembangya zaman dan dampak globalisasi, komoditas mengalami pergeseran makna bagi sebagian orang. Komoditas bukan lagi hanya berkaitan dengan benda atau barang, namun manusia pun dijadikan sebagai komoditas dalam upaya memperoleh keuntungan.

Beberapa tahun terakhir, isu perdagangan manusia (human trafficking) yang dijadikan sebagai komoditas perdagangan menjadi persoalan yang sangat serius yang dihadapi oleh dunia internasional. Isu human trafficking tersebut menjadi isu yang seksi untuk dibicarakan. Human trafficking menjadi suatu persoalan global yang hampir dialami atau dihadapi setiap negara, termasuk Indonesia.

Berdasarkan laporan PBB dan US Department of Justice (dalam Harkrisnowo, 2003: 7) mengungkapkan beberapa informasi terkait human trafficking antara lain:

- Di seluruh dunia, setiap tahunnya terdapat 700 ribu hingga empat juta orang diperjualbelikan di luar kemauannya;

- Sebagian besar korban human trafficking tersebut berasal dari negara-negara dengan tingkat ekonomi rendah, dan diperdagangkan ke negara-negara maju; 
- Sebagian besar korban merupakan wanita dan anak-anak;

- Peningkatan taraf hidup dan gaji yang menggiurkan merupakan janji yang sering digunakan para pelaku human trafficking untuk menggoda para korbannya.

- Umumnya korban dipaksa untuk menjadi pekerja seks, pekerja paksa, asisten rumah tangga, dan bahkan pengemis;

- Untuk mengendalikan mereka, upaya kekerasan atau ancaman kekerasan biasa dilakukan;

- Sekitar 2, 3 juta perempuan pekerja seks komersial tidak menginginkannya dan diprediksi sebanyak 40 persen adalah anak di bawah umur.

Human trafficking di Indonesia bukan suatu persoalan yang baru. Selama bertahun-tahun, permasalahan human trafficking seolah datang silih berganti dan tidak pernah berhenti. Berbagai upaya telah dilakukan pemerintah dalam memerangi human trafficking, namun tidak pernah berhasil menghentikan persoalan yang ada. Berdasarkan laporan Organisasi Internasional untuk Migrasi (IOM), korban human trafficking mencapai 74.616 hingga 1.000.000 per tahun di Indonesia dan terdapat korban human trafficking setiap satu detik (https://nasional.sindonews. com/read/1036327/15/korban humantrafficking-di-indonesia-capai-1-juta-pertahun-1440387040/, diakses 6 September 2019). Kasus perdagangan perempuan yang terjadi di Indonesia sebagian besar dilakukan oleh sindikat internasional yang terorganisasi, yaitu Malaysia sebagai negara tujuan. Pembuatan identitas palsu, paspor ilegal, dan berbagai cara lain merupakan modus operasi yang dilakukan oleh pelaku kejahatan human trafficking dalam upaya memindahkan perempuan sebagai komoditas untuk mendapatkan keuntungan besar (Pertiwi, 2018: 1).

Dalam beberapa tahun terakhir, Provinsi NTT identik dengan kejadian human trafficking. Provinsi NTT mendapat predikat terkait permasalahan human trafficking, yaitu daerah dengan kasus human trafficking tertinggi. Pada 2017, pemerintah menetapkan Provinsi NTT, Provinsi NTB, Provinsi Jawa Timur, dan Provinsi Jawa Barat sebagai daerah berzona merah terkait kasus human trafficking. Pada akhir 2017, Provinsi NTT mendapat predikat teratas sebagai Provinsi dengan kasus human trafficking terbanyak (http://www.verbivora.com/2018/04/telaahhuman-trafficking-di-indonesia.html/, diakses 06 September 2019). Tingginya angka kasus human trafficking di Provinsi NTT menyebabkan media sering memplesetkan NTT menjadi Nusa Trafficking Tinggi (NTT), sehingga beberapa kepala daerah (bupati) di Provinsi NTT juga dijuluki "Bupati Trafficking" (https://www.liputan6. com/regional/read/3407764/kisah-dibalik-julukan-bupati-trafficking-di-ntt/, diakses 6 September 2019). Dengan demikian, artikel ini bertujuan untuk mengkaji fenomena human trafficking di Provinsi NTT.

Kenyataan tersebut tentu sangat memprihatinkan. Namun yang menjadi pertanyaanya adalah faktor apa yang menyebabkan terjadinya human trafficking di Provinsi NTT? Bagaimana situasi human trafficking di Provinsi NTT? Solusi apa saja yang bisa dilakukan untuk mengatasi masalah human trafficking di Provinsi NTT?. Artikel ini bertujun untuk mengkaji 1) Realitas atau kondisi human trafficking di Provinsi NTT 2) faktor penyebab human trafficking di Provinsi NTT, dan 3) solusi untuk mengatasi human trafficking di Provinsi NTT. 


\section{Tinjauan Pustaka}

Konsep Dasar Perdagangan Manusia (Human Trafficking)

Undang-Undang Dasar Negara Republik Indonesia No. 21 tahun 2007 tentang pemberantasan tindak pidana perdagangan orang mengkonsepkan human trafficking sebagai suatu kegiatan mulai dari tahap perekrutan sampai dengan tahap penerimaan seseorang yang disertai dengan tindakan kekerasaan, penyekapan, penculikan, dan pemalsuan, sehingga memperolah persetujuan dari korban dengan tujuan eksploitasi, baik yang terjadi di dalam negeri maupun di luar negeri. Eksploitasi yang dimaksud merupakan sebuah tindakan pemaksaan terhadap sesorang untuk melakukan sesuatu perbuatan seperti pelacuran, kerja paksa, perbudakan, penindasan, pemerasan, pemanfaatan fisik, seksual, organ reproduksi atau secara melawan hukum mentransplantasi organ dan latau jaringan tubuh oleh pelaku untuk memperoleh keuntungan, baik materiil maupun immaterial.

Sedangkan PBB memberikan konsep human trafficking sebagai tindakan perekrutan, pengiriman, pemindahan, penampungan atau penerimaan seseorang, disertai ancaman atau kekerasan untuk mengeksploitasi seseorang dalam upaya memperoleh keuntungan (Farhana, 2010: 20). Pada intinya, konsep human trafficking memiliki tiga unsur yang saling berkaitan, yaitu 1) Tindakan atau perbuatan berupa perekrutan; 2) Cara, yaitu dengan menggunakan kekerasan, pemaksaan, dan ancaman; dan 3) Tujuan, yaitu, untuk mengeksploitasi seseorang, dalam bentuk seksual, kerja paksa, perbudakan atau transpaltasi organ tubuh.
Berdasarkan beberapa konsep tersebut, kegiatan human trafficking mencakup berbagai proses dan tindakan yang mengandung pemaksaan atau kekerasan dan berujung pada eksploitasi seseorang untuk mendapatkan keuntungan, baik material maupun immaterial.

\section{Human Trafficking di Dunia}

Persoalan human trafficking merupakan suatu hal yang sangat serius dan perlu mendapat perhatian khusus oleh setiap negara. Human trafficking merupakan masalah yang sangat kompleks. Fenomena human trafficking hampir terjadi di seluruh dunia dan dilakukan dengan berbagai modus serta rentan dialami oleh masyarakat dengan pengetahuan minim, kesulitan ekonomi, dan kesulitan mengakses dunia kerja, sehingga masyarakat sangat mudah untuk dibujuk. Sekretaris Jenderal PBB, Antonio Guterres, menyebut praktik human trafficking sebagai salah satu kategori kejahatan terhadap kemanusiaan.

International Labour Organization (ILO) memprediksi bahwa korban kerja paksa di seluruh dunia mencapai dua puluh satu juta orang dan merupakan korban human trafficking dan hal yang lebih miris adalah sebagian besar kasus human trafficking tersebut terjadi pada anak-anak. PBB memprediksi hampir sepertiga dari korbah human trafficking di seluruh dunia merupakan anak-anak dan sekitar 71 persen korban tersebut merupakan wanita dan anak perempuan (https://www.aa.com.tr/id/dunia/ pbb-sepertiga-dari-korban-perdagangan manusia-adalah-anak-anak/1217664/, diakses 1 April 2020). Fakta ini menunjukkan bahwa anak-anak dan perempuan merupakan kelompok yang sangat rentan menjadi korban human trafficking. 
Jumlah korban human trafficking sering berbeda, namunyang pastijumlahnyaakanterus bertambah, karena keadaan politik dan ekonomi yang tidak stabil. Pada 2018 PBB melaporkan bahwa, perempuan dan anak perempuan sering menjadi korban human traffickig global dan sekitar 59 persen mengalami eksploitasi seksual dan 34 persen lainnya menjadi korban kerja paksa (https://www.aa.com.tr/id/dunia/ pbb-korban-perdagangan-manusia-terbesaradalah-wanita-dan-anak perempuan/1544601, diakses 2 April 2020).

PBB menyadari tentang bahaya human trafficking bagi keberlangsungan hidup manusia dan kebebasan seseorang. Pada 30 Juli 2013, PBB mengadakan deklarasi sebagai hari menentang human trafficking sedunia untuk memerangi human trafficking sebagai upaya menambah kesadaran masyarakat terkait keadaan para korban human trafficking serta untuk melindungi hak para korban tersebut. Deklarasi tersebut merupakan salah satu bentuk tindakan PBB dalam memerangi human trafficking.

\section{Human Trafficking di Indonesia}

Human trafficking di Indonesia merupakan satu hal yang sering terjadi, bahkan sudah seperti roda yang tidak pernah berhenti berputar. Dengan kata lain, terdapat kasus human trafficking setiap tahun di Indonesia. Meski media massa sering memberitakan tentang hukuman bagi para pelaku human trafficking, hal tersebut belum bisa menghentikan fenomena human trafficking di Indonesia.

Berdasarkan catatan Organisasi Internasional untuk Migrasi (IOM), terdapat 6.651 kasus human trafficking di Indonesia pada periode Maret 2005 hingga Desember 2014. Dari jumlah tersebut, sekitar 82 persen merupakan wanita yang bekerja di sektor informal, baik yang bekerja di dalam maupun di luar negeri. Sekitar 18 persen merupakan laki-laki yang mayoritas mengalami eksploitasi ketika bekerja sebagai anak buah kapal (Daniel dkk., 2017: 23).

Sepanjang 2016 hingga pertengahan 2019, Kementerian Sosial Republik Indonesia mencatat, jumlah korban human trafficking di Indonesia mencapai 4.026 kasus dan cenderung mengalami peningkatan setiap tahun, meskipun dalam kurun dua tahun terakhir mengalami penurunan, dengan perincian sebagai berikut: 1377 kasus pada 2016, 1.838 kasus pada 2017, 1.079 kasus pada 2018 dan 732 kasus pada 2019 (https://akurat.co/fokus/id-704217-readsampai-pertengahan-tahun-ini-4906-orangindonesia-jadi-korban-mafia-perdaganganmanusia/, diakses 30 Maret 2020).

Seperti negara-negara lain, perempuan dan anak-anak sangat rentan terhadap human trafficking. Begitu juga di Indonesia, perempuan dan anak-anak dipaksa bekerja di berbagai sektor, seperti perdagangan seks dengan iming-iming kerja di restoran, pabrik, atau asisten rumah tangga, namun sebenarnya dijadikan pekerja seks komersial. Bahkan eksploitasi wanita di sektor domestik juga ditemukan. Selain itu, terjadi peningkatan jumlah mahasiswa dan pelajar sekolah yang masih di bawah 18 tahun untuk direkrut menjadi pekerja seks dengan menggunakan media sosial. Kepulauan Riau dan Bali merupakan tujuan utama pariwisata seks anak (https://id.usembassy.gov/id/ourrelationship-id/official-reports-id/laporantahunan-perdagangan-orang-2016/, diakses 30 Maret 2020).

\section{Metode}

Artikel ini menggunakan metode analisis deskriptif kualitatif berbasis kajian 


\section{Manusia yang Dijadikan Komoditas: Fenomena Human Trafficking \\ di Provinsi Nusa Tengggara Timur}

kepustakaan (library research) dengan menggunakan data sekunder dari berbagai sumber yang relevan. Kajian kepustakaan merupakan metode yang dilakukan dengan cara mengumpulkan data pustaka, membaca, mencatat, dan kemudian mengolahnya. Sedangkan Hadi (dalam Goma, 2020: 103) mendefinisikan studi kepustakaan sebagai kegiatan mengumpulkan data penelitian yang berasal dari perpustakaan dalam upaya menyelesaikan suatu penelitan.

\section{Pembahasan}

\section{Bentuk-bentuk Human Trafficking}

Human trafficking pada dasarnya merupakan bentuk eksploitasi terhadap seseorang. Ada berbagai macam bentuk human trafficking, seperti pekerja migran, pekerja anak, perdagangan anak melalui adopsi, pernikahan, dan implantasi organ tubuh.

\section{a. Pekerja Migran}

Secara konseptual, migran merupakan seseorang yang melakukan perpindahan antarwilayah dalam durasi waktu tertentu. Sedangkan pekerja migran merupakan orang yang berpindah dari daerah asal ke daerah tujuan dan bekerja di wilayah tujuan dalam durasi waktu tertentu. Berdasarkan cakupan wilayah perpindahanya, pekerja migran dapat dikategorikan dalam dua bentuk, yaitu pekerja migran internal dan pekerja migran internasional. Pekerja migran internal merupakan orang yang berpindah dari daerah asal ke daerah tujuan untuk bekerja dalam durasi waktu tertentu, tetapi masih dalam satu negara. Sedangkan migran internasional merupakan orang yang berpindah dari daerah asal dan pergi bekerja di daerah tujuan dalam durasi waktu tertentu serta melewati batas negara.

Mengirimkan tenaga kerja ke daerah lain atau negara lain berisiko mengalami human trafficking. Menurut catatan Organisasi Internasional untuk Migrasi (IOM) (dalam http://www.migrantcare.net/2018/03/ perdagangan-manusia-dan-korupsi-di-ntt/, diakses 06 September 2019), dalam kurun waktu Maret 2005 hingga Desember 2014, terdapat sekitar 82 persen kejadian human trafficking di Indonesia dialami oleh wanita yang telah bekerja di dalam dan di luar negeri untuk dieksploitasi.

\section{b. Pekerja Anak}

Fenomena pekerja anak memang bukan suatu hal yang baru untuk dibahas. Hampir semua negara di dunia memiliki pekerja yang masih berada dalam kategori anakanak. Pada 1998, berdasarkan Laporan UNICEF (dalam Harkrisnowo, 2003: 65), diperkirakan sekitar 30 persen pekerja seks di Indonesia adalah anak-anak di bawah 18 tahun (lebih dari 21.000 anak). Pada 1999, berdasarkan hasil kajian yang dilakukan oleh Organisasi Buruh International (ILO) terhadap tenaga kerja paksa anak-anak di jermal, hampir seluruh tenaga kerja yang bekerja pada anjungan-anjungan ini adalah anak-anak laki-laki berumur kurang dari 14 tahun. Jermal merupakan sebuah bangunan kayu yang diletakkan beberapa mil dari pantai dan terdiri atas anjungan seluas 20-40 meter persegi dan pondok kayu kecil yang digunakan untuk ruang tidur dan pengolahan ikan (International Organization for Migration, 2016: 64). Anak-anak lebih berisiko menjadi korban human trafficking dari orang dewasa karena mereka dianggap lebih mudah diatur dan tidak mengeluarkan banyak biaya. 


\section{c. Perdagangan Anak Melalui Adopsi}

Mengadopsi seorang anak merupakan hal yang lumrah yang tentu saja memiliki prosedur hukum yang harus ditaati. Namun, terkadang kata adopsi digunakan sebagian orang untuk menutup praktik perdagangan anak. Ada banyak modus yang dilakukan oleh para pelaku melalui adopsi. Pada umumnya para pelaku mencari ibu hamil yang memiliki kesulitan ekonomi dan pasangan suami istri yang tidak memiliki keturunan tetapi ingin memiliki anak. Para pelaku kemudian membujuk korban agar anaknya bisa diadopsi dan dapat hidup lebih layak, namun kemudian diperdagangkan.

\section{d. Implantasi Organ Tubuh}

Saat ini implantasi organ tubuh bukanlah sesuatu yang mustahil lagi untuk dilakukan. Perkembangan dunia kedokteran serta teknologi kedokteran memungkinkan terjadinya implantasi organ. Pada dasarnya implantasi organ di dunia kedokteran memiliki tujuan yang sangat baik. Namun, ada berbagai pihak tertentu yang menfaatkan keadaan untuk memperoleh keuntungan melalui praktik perdagangan organ tubuh manusia. Penculikan dan diambil organ tubuhnya untuk kemudian dijual kepada orang yang membutuhkan organ tubuh tersebut untuk ditransplantasi merupakan cara yang dilakukan oleh para pelaku transplantasi organ tubuh.

\section{e. Pernikahan}

Perdagangan manusia melalui pernikahan dibagi menjadi dua bentuk, yaitu Pertama, pernikahan yang diselubungi dengan praktik penipuan dengan tujuan membawa perempuan ke wilayah yang sangat asing, dan dijadikan pekerja seks komersial. Kedua, pernikahan dilakukan untuk mengeksploitasi perempuan pada sektor pekerjaan domestik (Farhana, 2010: 47-48).

\section{Human Trafficking di Provinsi NTT}

Kasus human trafficking di Provinsi NTT dalam beberapa tahun terakhir semakin banyak menghiasi pemberitaan di berbagai media cetak dan media daring, baik media lokal maupun media nasional. Status darurat human trafficking yang disematkan pada Provinsi NTT mengindikasikan banyaknya kasus human trafficking yang terjadi di Provinsi tersebut.

Para pelaku human trafficking di Provinsi NTT melakukannya secara terstruktur, artinya ada banyak orang yang terlibat di dalamnya, baik dilakukan secara perorangan maupun kelompok atau perusahaan. Pada April 2014 lalu misalnya, didapati keterlibatan Kadis Ketenagakerjaan Kabupaten Kupang dalam pembuatan dokumen perjalanan palsu untuk melindungi anak-anak yang diberangkatkan untuk menjadi pekerja migran (http://www. migrantcare.net/2018/03/perdagangan manusia-dan-korupsi-di-ntt/, diakses tanggal 06 septeptember 2019). Termasuk ditemukan 10 anggota Polda NTT dan tujuh jaringan yang terindikasi terlibat (https://www.voaindonesia. com/a/perdagangan-manusia-di-ntt/3489757. html, diakses 07 September 2019).

Banyak modus yang digunakan para pelaku kejahatan human trafficking dalam merekrut korban. Modus dengan menggunakan pendekatan secara budaya paling banyak dilakukan para pelaku kejahatan human trafficking di Provinsi NTT. Salah satu modus yang paling sering digunakan adalah uang sirih pinang. Pemberian uang sirih pinang 


\section{Manusia yang Dijadikan Komoditas: Fenomena Human Trafficking \\ di Provinsi Nusa Tengggara Timur}

dalam budaya Provinsi NTT merupakan salah satu bentuk penghargaan tamu kepada tuan rumah. Para pelaku mendekati keluarga korban dan memberikan uang sirih pinang dengan rata-rata dua juta hingga tiga juta rupiah, sehingga orang tua korban merasa terbebani dan terpaksa membiarkan anaknya untuk menjadi korban human trafficking (https://voxntt.com/2017/10/05/tahun-2017 -tercatat-137-kasus-human-trafficking-dintt/18488/, diakses 07 September 2019).

Menurut Kepolisian Daerah (Polda) NTT, dari data yang dihimpun dari 2015 hingga pertengahan 2016, terdapat 1.667 orang calon tenaga kerja wanita (TKW) asal NTT diberangkatkan dan menjadi korban human trafficking. Para calon TKW tersebut dikirim oleh beberapa sindikat human trafficking untuk bekerja di beberapa wilayah, seperti Medan, dan Malaysia. Pada periode 1 Januari 2015 hingga 31 Desember 2015, didapati 941 orang calon TKW yang dikirim. Selanjutnya didapati 726 orang juga diberangkatkan pada periode 1 Januari 2016 hingga Juli 2016 (https://regional.kompas. $\mathrm{com} / \mathrm{read} / 2016 / 08 / 23 / 09090061 / 1.667$. Calon.TKW.Asal.NTT.Jadi.Korban.Human. Trafficking, diakses 1 April 2020). Semua TKW tersebut menjadi korban jaringan pengiriman tenaga kerja. Jaringan tersebut adalah

perusahaan-perusahaan (https://www. voaindonesia.com/a/perdagangan-manusia -di-ntt/3489757.html, diakses 07 September 2019). Sementara itu dalam rentang waktu Januari hingga Agustus 2017, terdapat 137 kasus human trafficking di provinsi NTT (https://voxntt.com/2017/10/05/tahun-2017tercatat-137-kasus-human-trafficking-dintt/18488/, diakses 07 September 2019). Angka tersebut dilaporkan meningkat pada 2018, dimana pada 2018 terdapat 230 korban human trafficking di Provinsi NTT (https://www.victorynews.id/ntt-juara-humantrafficking/, diakses 1 April 2020).

Kasus human trafficking sering berdampak pada suatu hal yang buruk baik bagi korban maupun bagi keluarga korban, bahkan berujung pada kematian. Banyak pemberitaan di media massa tentang kasus kematian yang dialami para pekerja migran asal NTT yang merupakan korban human trafficking. Pada pemberitaan di sepanjang 2016 hingga awal 2018, terdapat 126 pekerja migran Indonesia asal Provinsi NTT yang meninggal di negeri Jiran, yaitu 46 orang meninggal pada 2016, 62 orang meninggal pada 2017, dan 18 orang meninggal pada Januari hingga Maret2018. Sebagian besar dari mereka yang meninggal merupakan korban human trafficking (http:// www.berdikarionline.com/human-traffickingdi-ntt/, diakses 07 september 2019).

Berdasarkan data dan fakta di atas, tidak heran jika pemerintah menetapkan darurat human trafficking untuk Provinsi NTT. Bahkan Presiden Jokowi pada tahun 2014 sudah menetapkan Provinsi NTT darurat human trafficking. Namun status darurat human trafficking tidaklah cukup untuk menghilangkan kasus human trafficking di Provinsi NTT.

\section{Faktor Penyebab Human Trafficking di Provinsi NTT}

\section{a. Faktor Ekonomi}

Hampir semua kasus human trafficking disebabkan oleh faktor ekonomi, seperti kemiskinan dan kurangnya ketersediaan lapangan pekerjaan. Kemiskinan berkaitan dengan kesempatan kerja. Angka kemiskinan yang tinggi biasanya berbanding terbalik dengan ketersediaan lapangan pekerjaan.

Faktor ekonomi yang dilatarbelakangi kemiskinan (http://rri.co.id/post/berita/407801/ 
daerah/kemiskinan_faktor_terjadinya human_trafficking_di_ntt.html, diakses 08 September 2019) dan ketersediaan lapangan pekerjaan (pengangguran) (https://indonesiatimur.co/2015/02/16/ini penyebab-utama-tingginya-kasus-humantrafficking-di-ntt/, diakses 08 September 2019) merupakan faktor utama penyebab masalah human trafficking di Provinsi NTT. Pada 2018, persentase penduduk miskin di Provinsi NTT sebesar 21,03 persen (www. bps.go.id, diakses 08 September 2019) dan menempati posisi tiga besar dengan jumlah penduduk miskin terbanyak di Indonesia bersama Provinsi Papua dan Papua Barat. Tingginya persentase penduduk miskin di Provinsi NTT berbanding terbalik dengan ketersediaan lapangan pekerjaan yang kemudian berdampak pada tingginya angka penggangguran. Pada Februari 2018, angka pengangguran terbuka di NTT sebesar 2,98 persen lalu naik menjadi 3,01 persen pada Agustus 2018 (www.bps.go.id, diakses 08 September 2019).

Situasidan kondisi tersebut menyebabkan banyak penduduk NTT memilih bermigrasi ke daerah lain. Tidak terpenuhinya kebutuhan di daerah asal dan kemungkinan terpenuhi di daerah tujuan merupakan alasan yang mendasar bagi sesorang untuk berpindah ke wilayah lain. Seperti yang diungkapkan oleh Everetst Lee, Todaro, dan Titus bahwa motivasi sesorang untuk berpindah adalah motif ekonomi dan hal tersebut merupakan sebuah pilihan yang rasional (Mantra, 2013).

\section{b. Faktor Pendidikan}

Selain faktor ekonomi, rendahnya tingkat pendidikan yang berdampak pada rendahnya kualitas sumber daya manusia (SDM) para pekerja asal NTT merupakan salah satu penyebab terjadinya human trafficking di Provinsi tersebut. Para korban kurang memahami bahwa regulasi ketenagakerjaan menjadi celah bagi berkembangnya human trafficking di NTT. Pada 2015 angka melek huruf di Provinsi NTT hanya sebesar 94,87 persen atau masih jauh di bawah rata-rata angka melek huruf secara nasional pada 2015, yaitu 97,71 persen. Situasi tersebut juga terjadi pada 2019, yaitu angka melek huruf di Provinsi NTT hanya sebesar 95,76 persen atau masih jauh di bawah rata-rata angka melek huruf secara nasional sebesar 98,22 persen (www.bps.go.id, diakses 2 April 2020).

Persoalan serupa juga terjadi pada indikator rata-rata lama sekolah penduduk NTT, di mana dari 2015 hingga 2019, ratarata lama sekolah penduduk di Provinsi NTT secara umum berada di bawah rata-rata lama sekolah penduduk secara nasional. Pada 2015, rata-rata lama sekolah penduduk di Provinsi NTT sebesar 7,40 dan pada 2015, rata-rata lama sekolah penduduk secara nasional sebesar 8,32; rata-rata lama sekolah penduduk di Provinsi NTT sebesar 7,54 pada 2016 dan rata-rata lama sekolah penduduk secara nasional sebesar 8,42 ; rata-rata lama sekolah penduduk di Provinsi NTT sebesar 7,62 pada 2017 dan rata-rata lama sekolah penduduk secara nasional sebesar 8,50 ; ratarata lama sekolah penduduk di Provinsi NTT sebesar 7,70 pada 2018 dan rata-rata lama sekolah penduduk secara nasional sebesar 8,58; rata-rata lama sekolah penduduk di Provinsi NTT sebesar 7,98 pada 2019 dan rata-rata lama sekolah penduduk secara nasional sebesar 8,75 (www.bps.go.id, diakses 2 April 2020).

Terdapat banyak contoh kasus korban human trafficking di Provinsi NTT yang memiliki tingkat pendidikan yang rendah. Sebagian besar TKI asal Provinsi NTT hanya 
lulus pendidikan Sekolah Dasar (SD) atau bahkan tidak lulus Pendidikan Sekolah dasar (SD) (http://floresa.co/2018/04/12/kadistenaga-kerja-ntt-beberkan-alasan-maraknyatki-ilegal/, diakses 08 September 2019). Kasus korban human trafficking yang menimpa Wilfrida Soic, misalnya, seorang TKW asal NTT yang berlatarbelakang pendidikan tidak lulus pendidikan Sekolah Dasar (SD) menjadi korban dari pelaku yang mengirimnya ke luar negeri tanpa membawa dokumen apa pun (Daniel dkk., 2017: 26).

Solusi Mengatasi Human Trafficking di Provinsi NTT

Mengatasi human trafficking di Provinsi NTT bukanlah suatu perkerjaan yang mudah dan membutuhkan keterlibatan berbagai pihak karena pada kenyataannya kasus human trafficking di Provinsi NTT sudah sangat mengakar dan terjadi secara sistematis melalui keterlibatan berbagai pihak. Keluarga hingga aparat penegak hukum pun terlibat dalam fenomena human trafficking di Provinsi NTT. Berbagai tindakan dapat dilakukan untuk memecahkan persoalan human trafficking di Provinsi NTT antara lain:

\section{a. Tindakan Preventif}

Melakukan sosialisasi kepada masyarakat melalui seminar, lokakarya, dan berbagai kegiatan sejenis yang mampu membuka pikiran masyarakat terkait modus dan dampak human trafficking merupakan tindakan preventif yang dapat dilakukan. Pemerintah, LSM, serta pihak-pihak terkait dapat bekerjasama dalam kegiatan tersebut agar masyarakat tidak mudah tertipu dan dibohongi oleh para pelaku human trafficking yang menawarkan janji-janji manis kepada calon korban.
Pemerintah pusat maupun pemerintah Provinsi NTT pada dasarnya telah melakukan berbagai tindakan preventif dalam upaya mengurangi bahkan menghentikan kasus human trafficking di Indonesia, khusunya di Provinsi NTT. Pemerintah Pusat melalui Kementerian Dalam Negeri telah memerintahkan Gubernur/Bupati/Walikota melalui instruksi No. 183/373/Sj 2016 tentang Pencegahan, Penanganan, dan Pemulangan Korban TPPO (https://mediaindonesia.com/ $\mathrm{read} /$ detail/64632 12 rekomendasi mendesak dilaksanakan, diakses 3 April 2020) merupakan salah satu tindakan preventif yang dilakukan pemerintah pusat dalam menanggulangi kasus human trafficking di Indonesia.

Pemerintah Provinsi NTT juga tidak diam melihat maraknya kasus human trafficking ini. Pengarusutamaan Gender (PuG) dalam pembangunan merupakan salah bentuk keseriusan Pemprov NTT dalam upaya menghapus human trafficking di Provinsi NTT. Pemprov NTT juga melakukan berbagai kebijakan seperti melakukan peninjauan ulang TKI asal NTT, baik yang sudah atau akan bekerja di luar negeri. Meningkatnya kasus pelanggaran HAM dan human trafficking terhadap TKI asal NTT di luar negeri yang berujung pada kematian merupakan alasan mendasar dilakukannya kegiatan tersebut (Utami, 2019: 199).

Dikeluarkannya Surat Keputusan Gubernur NTT No. 357/KEP/HK/2018 tanggal 14 November 2018 tentang moratorium pengiriman TKI asal NTT juga merupakan salah satu upaya preventif pemerintah Provinsi NTT untuk mengatasi human trafficking. Sementara itu, Dinas Pemberdayaan Perempuan dan Perlindungan Anak (DP3A) Provinsi NTT juga melaksanakan pelatihan SDM bagi penyedia layanan pada Agustus 2019 (Utami, 2019: 199). 
Pemprov NTT juga mengadakan kerja sama dengan gereja untuk memecahkan berbagai persoalan di NTT. Wakil Gubernur Provinsi NTT, Josef Nai Soi, mengatakan bahwa perlunya adanya kerja sama antara pemerintah Provinsi NTT dan gereja untuk mengatasi berbagai persoalan yang ada di Provinsi NTT. Hal ini diharapkan dapat membangkitkan NTT dari permasalahan, termasuk human trafficking (https://www. beritasatu.com/nasional/523099-gerejadan-pemerintah-perlu-kerja-sama-atasipersoalan-di-ntt, diakses 3 April 2020).

Berbagai upaya preventif tersebut merupakan salah satu upaya pemerintah Provinsi NTT menghapus kasus human trafficking di Provinsi NTT. Meskipun Provinsi NTT belum bebas dari human trafficking, adanya berbagai tindakan preventif yang dilakukan oleh pemerintah dan berbagai elemen masyarakat setidaknya dapat mengurangi kasus human trafficking di Provinsi NTT.

\section{b. Tindakan Pemberdayaan}

Ketersediaan lapangan pekerjaan yang kurang memadai dan jeratan kemiskinan serta pengangguran merupakan persoalan yang sering dihadapi masyarakat NTT dan merupakan cikal bakal timbulnya kasus human trafficking. Pada 2014, jumlah penduduk miskin di Provinsi NTT sebanyak 99,88 ribu orang (19,60 persen) (BPS NTT, 2015), lalu meningkat menjadi $1.160,53$ ribu orang $(22,58$ persen) pada 2015 (BPS NTT, 2016). Pada 2016, jumlah penduduk miskin di Provinsi NTT sebesar 1.150,08 ribu orang $(22,01$ persen) (BPS NTT, 2017) dan pada 2017 sebesar 1.134,74 ribu orang (21,38 persen) (BPS NTT, 2018). Pada 2018, Provinsi NTT menempati posisi tiga besar dengan jumlah penduduk miskin terbanyak bersama Provinsi Papua dan Papua Barat.

Angka kemiskinan yang tinggi berbanding lurus dengan meningkatnya angka pengangguran di Provinsi NTT, dimana jumlah pengangguran di Provinsi NTT cenderung mengalami peningkatan dari 2014 hingga 2018. Pada 2014, jumlah pengangguran di Provinsi NTT adalah 73.210 orang, lalu mengalami peningkatan pada 2015 menjadi 88.446 orang. Pada 2016, 76.580 orang yang menganggur di Provinsi NTT, dan meningkat menjadi 78.548 orang pada 2017. Pada 2018, terdapat 74.748 orang menganggur di Provinsi NTT (www.ntt.bps.go.id, diakses 01 April 2020.)

Tindakan pemberdayaan masyarakat juga menjadi solusi yang dapat dilakukan untuk mengatasi masalah kemiskinan dan pengangguran di Provinsi NTT. Pemberdayaan masyarakat melalui pelatihan keterampilan dan kewirausahan dapat menumbuhkan lapangan pekerjaan baru bagi masyarakat. Bekal keterampilan yang dimiliki dapat digunakan untuk membuka usaha-usaha mikro untuk meningkatkan perekonomian keluarga.

\section{c. Perbaikan Sistem Ketenagakerjaan}

Dinas Ketenagakerjaan Provinsi NTT merupakan instansi pemerintah daerah yang paling disorot terkait maraknya kasus human trafficking di NTT. Untuk mengatasi permasalahan human trafficking di NTT, pemerintah daerah perlu melakukan berbagai evaluasi, seperti pertama, perlu adanya evaluasi terkait perijinan dan legalitas PJTKI yang berada di wilayah NTT, yaitu tindakan tegas jika ditemukan PJTKI ilegal yang beroperasi di wilayah NTT. Kedua, perlu adanya pengawasan internal pada dinas 


\section{Manusia yang Dijadikan Komoditas: Fenomena Human Trafficking \\ di Provinsi Nusa Tengggara Timur}

terkait (Dinas Ketenagakerjaan), sehingga tidak ada oknum instansi terkait (pegawai dinas ketenagakerjaan) yang terlibat dalam rantai human trafficking di Provinsi NTT karena di beberapa kasus telah ditemukan adanya keterlibatan pegawai dinas ketenagakerjaan Provinsi NTT (http://www.migrantcare. net/2018/03/perdagangan-manusia-dankorupsi-di-ntt/, diakses 06 september 2019). Ketiga, membangun kerja sama dengan berbagai instansi pemerintah, kepolisian, dan LSM untuk meningkatkan pengawasan dalam upaya pencegahan tindakan human trafficking di Provinsi NTT.

\section{Kesimpulan}

Human trafficking merupakan permasalahan yang perlu mendapat perhatian serius. Permasalahan human trafficking di Indonesia bukan suatu hal yang baru, yaitu telah berlangsung lama dan hampir terjadi setiap tahun. Provinsi NTT sebagai salah satu penyumbang utama kasus human trafficking di Indonesia menyadari bahaya dan dampak dari human trafficking.

Human trafficking merupakan sebuah bentuk eksploitasi terhadap seseorang, dan merupakan sebuah tindakan kejahatan yang beberapa tahun terakhir sering terjadi serta menghiasi pemberitaan di media massa, baik media cetak maupun daring. Pekerja migran, pekerja anak, pernikahan, implantasi organ tubuh, dan perdagangan anak melalui adopsi merupakan beberapa bentuk human trafficking yang sering terjadi.

Pada 2017, Provinsi NTT menempati urutan pertama terkait kasus human trafficking di Indonesia. Realitas tersebut sangat memprihatinkan dan menimbulkan banyak pertanyaan terkait faktor utama penyebab terjadinya fenomena human trafficking di
Provinsi NTT. Berdasarkan realitas dan hasil kajian sebelumnya, faktor ekonomi, seperti kemiskinan dan kurangnya lapangan pekerjaan yang kemudian berdampak pada tingginya angka pengangguran, merupakan faktor utama terjadinya human trafficking di Provinsi NTT.

Pada 2018, persentase penduduk miskin di Provinsi NTT adalah 21, 03 persen dan berada pada urutan ketiga dengan jumlah penduduk miskin terbanyak setelah Provinsi Papua dan Papua Barat. Tingginya persentase penduduk miskin di Provinsi NTT berbanding terbalik dengan ketersediaan lapangan pekerjaan yang kemudian berdampak pada tingginya angka penggangguran. Pada Februari 2018, angka pengangguran terbuka di NTT sebesar 2,98 persen, lalu naik menjadi 3,01 persen pada Agustus 2018.

Rendahnya sumber daya mansusia (SDM) sebagai dampak dari rendahnya tingkat pendidikan juga merupakan salah satu faktor utama terjadinya human trafficking di Provinsi NTT. Pada 2015, angka melek huruf di Provinsi NTT hanya sebesar 94,87 atau masih berada jauh di bawah rata-rata angka melek huruf secara nasional, yaitu sebesar 97,71 pada 2015 . Hal yang sama juga terjadi pada tahun-tahun selanjutnya, yaitu pada 2019, angka melek huruf di Provinsi NTT hanya sebesar 95,76 dan masih berada jauh di bawah rata-rata angka melek huruf secara nasional sebesar 98,22. Hal yang sama juga terjadi pada indikator rata-rata lama sekolah penduduk di Provinsi NTT, dimana dari tahun 2015 hingga 2019, rata-rata lama sekolah penduduk di Provinsi NTT secara umum masih berada di bawah rata-rata lama sekolah penduduk secara nasional.

Untuk mengatasi hal tersebut, perlu adanya solusi konkrit dari berbagai pihak untuk menekan terjadinya kasus human trafficking 
di Provinsi NTT. Tindakan preventif, tindakan pemberdayaan masyarakat, dan perbaikan sistem ketenagakerjaan merupakan tiga solusi yang bisa dilakukan untuk menekan tejadinya kasus human trafficking di Provinsi NTT.

\section{Daftar Pustaka}

aa.com.tr. (2018). "PBB: Sepertiga Dari Korban Perdagangan Manusia Adalah AnakAnak" https://www.aa.com.tr/id/dunia/ pbb-sepertiga-dari-korban-perdaganganmanusia-adalah-anak-anak/1217664. Diakses 1 April 2020.

aa.com.tr. (2019). "PBB: Korban Perdagangan Manusia Terbesar Adalah Wanita Dan anak Perempuan". https://www.aa.com. $\mathrm{tr} / \mathrm{id} / \mathrm{dunia} / \mathrm{pbb}$-korban-perdaganganmanusia-terbesar-adalah-wanita-dananak-perempuan/1544601. Diakses 2 April 2020.

akurat.co. (2019). "Sampai Pertengahan Tahun Ini, Ada 4.906 Orang Indonesia Jadi Korban Mafia Perdagangan Manusia". https://akurat.co/fokus/id-704217-readsampai-pertengahan-tahun-ini-4906orang-indonesia-jadi-korban-mafiaperdagangan-manusia. Diakses 30 Maret 2020.

Berdikarionline.com. (2018). "Human Trafficking di NTT". http://www. berdikarionline.com/human-trafficking-dintt/. Diakses 7 September 2019.

beritasatu.com. (2018). "Gereja dan pemerintah Perlu Kerja Sama Atasi Persoalan di NTT". https://www. beritasatu.com/nasional/523099-gerejadan-pemerintah-perlu-kerja-sama-atasipersoalan-di-ntt. Diakses 3 April 2020.

BPS NTT. (2015). Profil Kemiskinan Provinsi Nusa Tenggara Timur Tahun 2014. Kupang: BPS NTT.
BPS NTT. (2016). Profil Kemiskinan Provinsi Nusa Tenggara Timur Tahun 2015. Kupang: BPS NTT.

(2017). Profil Kemiskinan Provinsi Nusa Tenggara Timur Tahun 2016. Kupang: BPS NTT. (2018). Profil Kemiskinan Provinsi Nusa Tenggara Timur Tahun 2017. Kupang: BPS NTT.

Daniel, E.S. Rider, Mulyana, Nandang, dan Wibhawa, Budi. (2017). "Human Trafficking Di Nusa Tenggara Timur" Social Work Vol. 7 No. 1.

Farhana. (2010). Aspek Hukum Perdagangan Orang di Indonesia. Jakarta: Sinar Grafika. Floresa.co. (2018). "Kadis Tenaga Kerja NTT Beberkan Alasan Maraknya TKI Ilegal". floresa.co/2018/04/12/kadis tenaga kerja ntt beberkan alasan maraknya tki ilegal/. Diakses 8 September 2019.

Goma, Edwardus Iwantri. (2020). "Situasi Keluarga Berencana di Provinsi Kalimantan Timur" Georafflesia Vol. 4, No.2

Harkrisnowo. (2003). Laporan Perdagangan Manusia di Indonesia. Jakarta: Sentra HAM UI.

id.usembassy.gov. (2016). "Laporan Tahunan Perdagangan Orang 2016". https:// id.usembassy.gov/id/our-relationshipid/official-reports-id/laporan-tahunanperdagangan-orang-2016/. Diakses 30 Maret 2020.

indonesiatimur.com. (2015). "Penyebab Utama Tingginya Kasus Human Trafficking di NTT". https://indonesiatimur. co/2015/02/16/ini-penyebab-utamatingginya-kasus-human-trafficking-di-ntt/. Diakses 8 September 2019.

International Organization for Migration. (2016). Laporan Mengenai Perdagagangan Orang, Pekerja Paksa dan Kejahatan Perikanan Dalam Industri Perikanan Di Indonesia. Jakarta: IOM. 
Liputan6.com. (2018). "Di Balik Julukan Bupati Trafficking di NTT “. https://www.liputan6. com/regional/read/3407764/kisah di balik julukan bupati trafficking di ntt. Diakses 6 September 2019.

Mantra. (2013). DemografiUmum. Yogyakarta: Pustaka Pelajar.

mediaindonesia.com.

(2016). "12

Rekomendasi Mendesak Dilaksanakan" https://mediaindonesia.com/read/ detail/64632-12-rekomendasi-mendesakdilaksanakan. Diakses 3 April 2020.

Migrantcare.net. (2018).“Perdagangan

Manusia dan Korupsi di NTT “.http://www. migrantcare.net/2018/03/perdagangan manusia-dan-korupsi-di-ntt/. Diakses tanggal 6 September 2019.

Pemerintah Indonesia. (2007). UndangUndang Republik Indonesia Nomor 21 tahun 2007 tentang Pemberantasan Tindak Pidana Perdagangan Orang. Lembaran RI Tahun 2007 No. 4720. Jakarta: Sekertariat Negara.

Pertiwi, Hanako Fatimah. (2018). "Analisis Modus Operandi Sindikat Women Trafficking (Studi atas Tiga Kasus Human Trafficking dari NTT dan Jakarta ke Malaysia)". Jurnal Kriminologi Indonesia Vol. 14 No. 1.

regional.kompas.com. (2016). "Calon

TKW Asal NTT Jadi Korban Human Trafficking". https://regional.kompas.com/ $\mathrm{read} / 2016 / 08 / 23 / 09090061 / 1.667$.Calon. TKW.Asal.NTT.Jadi.Korban.Human. Trafficking. Diakses 1 April 2020.

rri.co.id.(2017). "Kemiskinan Faktor Terjadinya Human Trafficking di NTT". http://rri.co.id/ post/berita/407801/daerah/kemiskinan_ faktor_terjadinya_human_trafficking_di_ ntt.html. Diakses 8 September 2019.

Sindonews.com. (2015). "Korban Human Trafficking di Indonesia Capai 1 Juta
Per Tahun". https://nasional.sindonews. com/read/1036327/15/korban human trafficking di indonesia capai-1-juta-pertahun-1440387040 diakses 6 September 2019.

Utami, Penny Naluria. (2019). "Penanganan Kasus Tindak Pidana Perdagangan Orang Oleh Pemerintah Provinsi Nusa Tenggara Timur". Jurnal HAM, Volume 10 no. 2.

Verbivora.com.(2018). "Telaah Human Trafficking di Indonesia". http://www. verbivora.com/2018/04/telaah-humantrafficking-di-indonesia.html. Diakses 6 September 2019.

victorynews.id. (2019)." NTT Juara Human Trafficking". https://www.victorynews. id/ntt-juara-human-trafficking/. Diakses 1 April 2020.

VOAIndonesia.com. (2016).

"Fenomena Perdagangan Manusia di NTT". https://www.voaindonesia. com/a/perdagangan-manusiadi-ntt-/3489757.html. Diakses 7 September 2019.

VoxNTT.com. (2017). "Tahun 2017 Tercatat 137 Human Trafficking di NTT". https:// voxntt.com/2017/10/05/tahun-2017tercatat-137-kasus-human-traffickingdi-ntt/18488/. Diakses 7 September 2019.

www.bps.go.id. Diakses 8 September 2019.

www.bps.go.id. Diakses 2 April 2020. www.ntt.bps.go.id. Diakses 1 April 2020. 